\title{
Identification of Visibility Reducing Weather Phenomena Due to Aerosols
}

\author{
Soon-Ung Park (Corresponding author) \\ Center for Atmospheric and Environmental Modeling \\ Seoul National University Research Park RM. 515
}

San 4-2, Bongcheon-dong, Gwanak-gu, Seoul, 151-919, Korea

Tel: 82-2-885-6712Ｅ-mail: supark@snu.ac.kr

Jeong-Hoon Cho

Center for Atmospheric and Environmental Modeling

Seoul National University Research Park RM. 515

San 4-2, Bongcheon-dong, Gwanak-gu, Seoul, 151-919, Korea

Tel: 82-2-885-6712Ｅ-mail: jeonghoon.cho@gmail.com

\section{Moon-Soo Park}

Center for Atmospheric and Environmental Modeling

Seoul National University Research Park RM. 515

San 4-2, Bongcheon-dong, Gwanak-gu, Seoul, 151-919, Korea

Tel: 82-2-885-6712Ｅ-mail: moonsoo@paran.com

Received: April 5, $2013 \quad$ Accepted: April 19, 2013

doi:10.5296/emsd.v2i1.3628ＵRL: http://dx.doi.org/10.5296/emsd.v2i1.3628

\begin{abstract}
Visibility reduction is usually caused by hydrometeor and lithometeor such as precipitation, fog, mist, haze, and dust. Among these weather phenomena the distinction of mist, haze and Asian dust is very difficult for naked observers especially for the case of mist and damp haze.
\end{abstract}


A method for the distinction of mist, haze and Asian dust has been developed using the synoptic surface weather reporting data and the size segregated aerosol data $\left(\mathrm{PM}_{1}, \mathrm{PM}_{2.5}\right.$ and $\mathrm{PM}_{10}$ ) monitored at six sites over South Korea for three years (2009 to 2011). It is found that mist can be identified from haze with the use of observed water vapor mixing ratio and its 15-day trend curve for the data exceeding the minimum $\mathrm{PM}_{10}$ concentration that causes visibility reduction at each monitoring site; Asian dust events are identified with conditions of hourly mean $\mathrm{PM}_{10}$ concentration exceeding $90 \mu \mathrm{g} \mathrm{m} \mathrm{m}^{-3}$ and the ratio of $\mathrm{PM}_{10} / \mathrm{PM}_{1} \geqslant 4$. It is also found that the visibility reducing weather events (occurrence frequency) are haze (23\%), mist $(19 \%)$, precipitation $(13 \%)$, fog $(9 \%)$ and Asian dust $(1.1 \%)$ in order at the island site, while those events (occurrence frequency) are haze (29\%), mist (21\%), precipitation (13\%), Asian dust $(2.1 \%)$ and fog $(0.3 \%)$ in order at the inland site, indicating more frequent occurrence of fog events at the island site. However, haze and mist events are found to occur most frequently at both the island and the inland sites caused by anthropogenic aerosols.

Keywords: Aerosols, Asian dust, Haze, Mist, Visibility reduction, Weather event

\section{Introduction}

Atmospheric aerosols can affect the quality of our lives significantly because of its potential impacts on human health and the environment. Aerosols in the sub-micrometer size range can be inhaled and thus may pose certain health hazards (Bates et al., 1966; Pope et al., 1992; Dockery et al., 1992; 1993a; 1993b; Binkowski and Shankar, 1995; Balásházy et al., 2003; Yadav et al. 2003; Davis et al., 2010). Because aerosols also scatter light, they strongly influence the radiative budget of the Earth-atmosphere system; they also reduce visibility and diminish the aesthetic scenery (IPCC, 1996; Jacobson, 2001; Lee and Sequeira, 2001; Kaufman et al., 2002; Watson, 2002; Crutzen, 2004; Chang and Park, 2004; Penner et al., 2004; Park et al., 2005; Jung et al, 2009). Visibility reduction is usually caused by weather phenomena such as precipitation, fog, mist, haze and dust that are associated with hydrometeor and lithometeor.

East Asia is a major source of both natural aerosol (Asian dust) and anthropogenic aerosols over the Northern Hemisphere. Asian dust that is a typical example of mineral aerosol occurs in northern China and Mongolia more frequently during the spring season (Gao et al., 2000; Husar et al., 2001; In and Park, 2003; Park and In, 2003; Park and Lee, 2004; Yu et al., 2011) and has its increasing occurrence trend due to desertification in the source region. Anthropogenic aerosols that are mainly originated from emitted pollutants have also an increasing trend due to the rapid economic expansion in many Asian countries (Chun and Lim, 2004; Lee et al, 2006; Kim et al., 2008; Park et al., 2012a). Tropospheric aerosols in this region are the complex mixture of various aerosols such as Asian dust and anthropogenic aerosols. Consequently, occurrence frequencies of visibility reducing weather events caused by aerosols have an increasing trend, especially over Asia (Che and Zhang, 2007; Gautam et al., 2007; Wang et al., 2009; Gao et al., 2011; Guo et al., 2013;)

Visibility reducing weather phenomena caused by aerosols include precipitation, fog, mist, haze and dust storm. Precipitation is defined as any or all of the forms of water particles, whether liquid or solid, that fall from the atmosphere and reach the ground (AMS, 2000), so 
that it can be easily identified by the observer. Fog is defined as a hydrometeor suspended in the atmosphere near the earth's surface (AMS, 2000). Fog reduces visibility below one kilometer and this criterion is implemented in Korea Meteorological Administration (KMA) with the condition of the relative humidity above $75 \%$ for the observation of fog. However, the criterion of the relative humidity for fog is not well defined (UKMO, 1994). Mist is defined as a hydrometeor consisting of an aggregate of microscopic and more-or-less hygroscopic water droplets suspended in the atmosphere. Mist produces a thin, greyish vein over the landscape and reduces visibility to a lesser extend than fog. The relative humidity with mist is often less than $95 \%$. Mist is intermediate in all respects between haze and fog (AMS, 2000). The criteria for the observation of mist are the relative humidity $(\mathrm{RH}) \geqslant 75 \%$ and visibility (VIS) $<10 \mathrm{~km}$ that are used in KMA. However, these conditions are not used in WMO and other institutes (WMO, 2008a; 2008b).

Haze is defined as fine dust or salt particles dispersed through a portion of the atmosphere; a type of lithometeor. The particles are so small that they cannot be felt or individually seen with the naked eye, but they diminish horizontal visibility and give the atmosphere a characteristic opalescent appearance that subdues all colors. Haze formations are caused by the presence of an abundance of condensation nuclei which may grow in size to become mist, fog or cloud (AMS, 2000). The criteria for the observation of haze used in KMA are RH < $75 \%$ and VIS $<10 \mathrm{~km}$. However these criteria are not used in WMO (WMO, 2008b).

Asian dust aerosol is soil originated mineral aerosols originated from the Asian dust source regions in northern China and Mongolia. So far there is no commonly accepted definition for the Asian dust.

The purpose of this study is to develop a methodology to identify weather events caused by aerosols with the used of the synoptic surface observation data and the size segregated aerosol $\left(\mathrm{PM}_{1}, \mathrm{PM}_{2.5}, \mathrm{PM}_{10}\right)$ concentration data observed at several sites in Korea for three years (2009 to 2011) and to implement this methodology for the analysis of the occurrence frequency of each weather event in South Korea.

\section{Used data}

The data used in this study are hourly observed surface meteorological data and the size segregated aerosol concentration data with three steps $\left(\mathrm{PM}_{1}, \mathrm{PM}_{2.5}, \mathrm{PM}_{10}\right)$ measured at the 5-minute interval at 6 monitoring sites over South Korea (Figure 1) for three years (2009 to 2011). These data are obtained from KMA. 


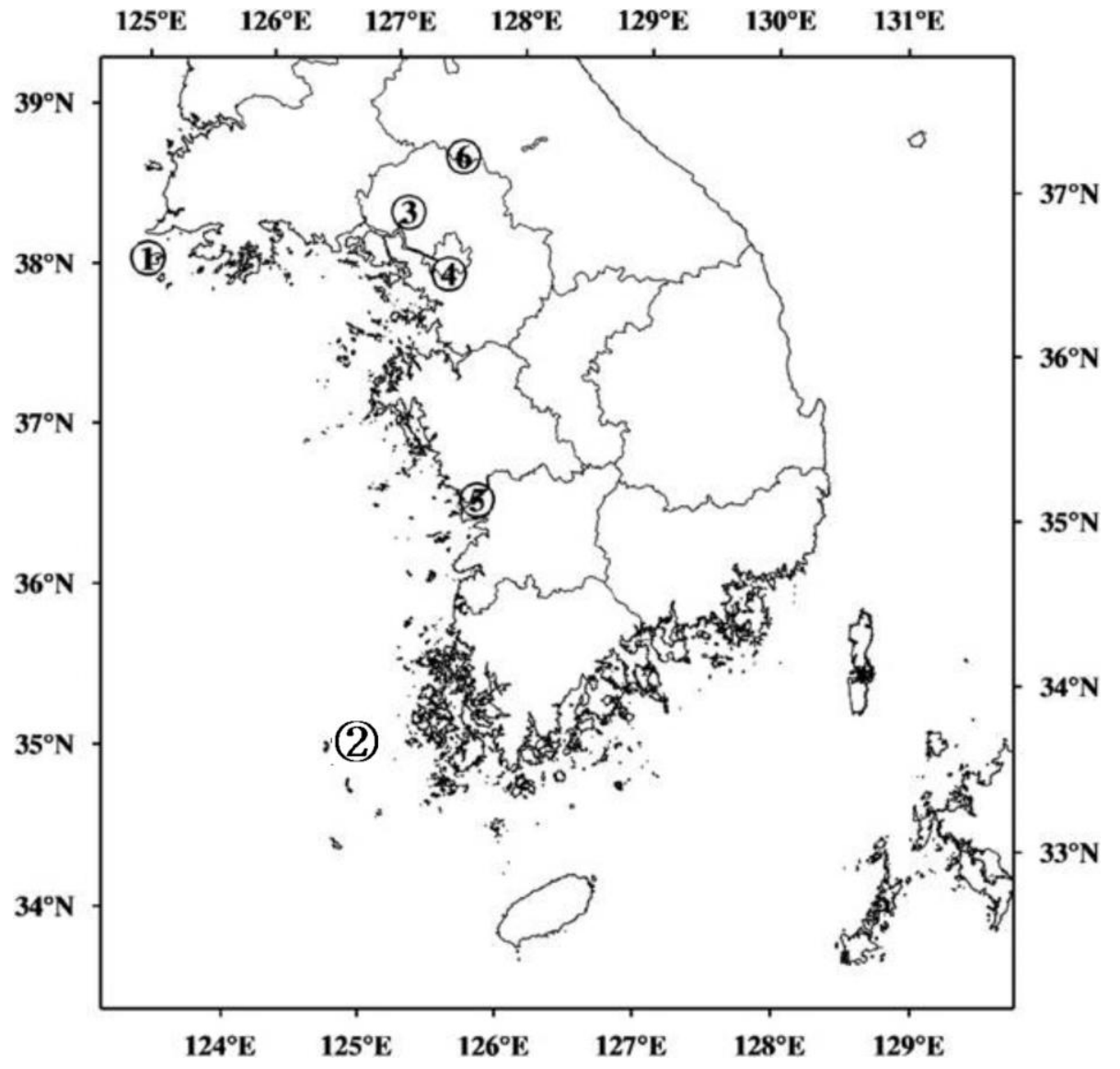

Figure 1. Locations of monitoring sites; (1) Baengnyeongdo, (2) Heuksando, (3) Munsan, (4) Seoul, (5) Gunsan and (6) Cheorwon

\section{Methodology for the Identification of Weather Events Caused by Aerosols}

The size segregated aerosol concentrations measured at a 5-minute interval are averaged for one hour and then smoothed by taking weighted running mean with 5 weighting coefficients from the binominal function to make hourly averaged data that are compatible to the surface observation data. The hourly mean size segregated aerosol concentration data are used for the further analysis.

The precipitation events are identified with the use of 3-year time series of the hourly surface observation data at each site.

The fog events are identified with the reporting data of KMA that are obtained from the time series of the hourly surface observation data at each site.

To determine the lowest $\mathrm{PM}_{10}$ concentration that affects visibility reduction at each site, the data that satisfy the condition of visibility (VIS) $>20 \mathrm{~km}$ from both time series of the surface observation data and the hourly mean $\mathrm{PM}_{10}$ concentration data that are excluded the precipitation and the fog events are chosen and then constructed an occurrence probability density function with respect to the $\mathrm{PM}_{10}$ concentration at each site. The lowest $\mathrm{PM}_{10}$ 


\section{Macrothink}

concentration that affects visibility is determined by taking the $\mathrm{PM}_{10}$ concentration value at the cumulative occurrence probability density function of $80 \%$. Figure 2 shows the occurrence probability density function and the lowest $\mathrm{PM}_{10}$ concentration that affects visibility at the monitoring sites over Korea. This value is used to identify mist from dust.

(a) Baengnyeongdo

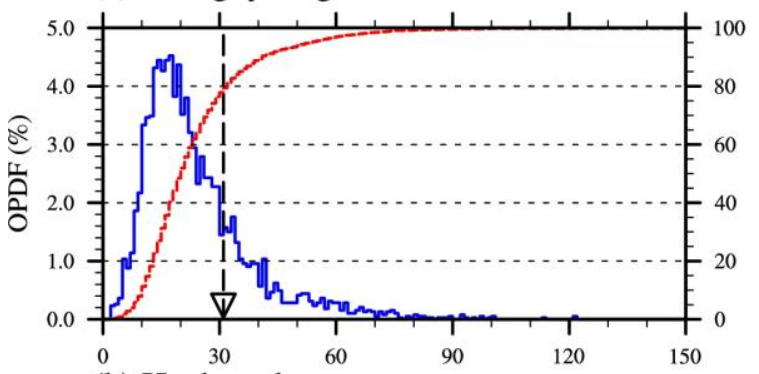

(b) Heuksando

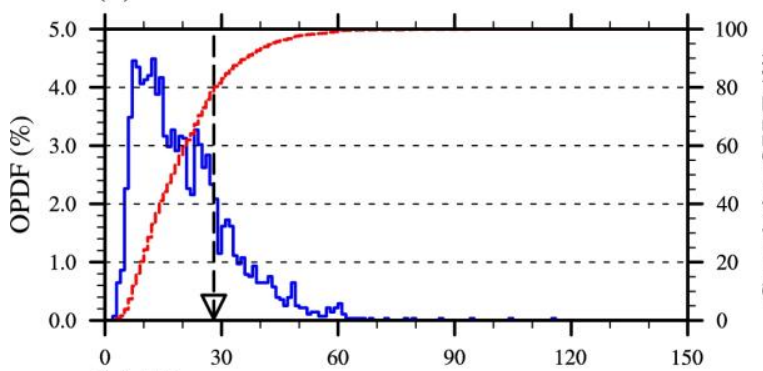

(c) Munsan

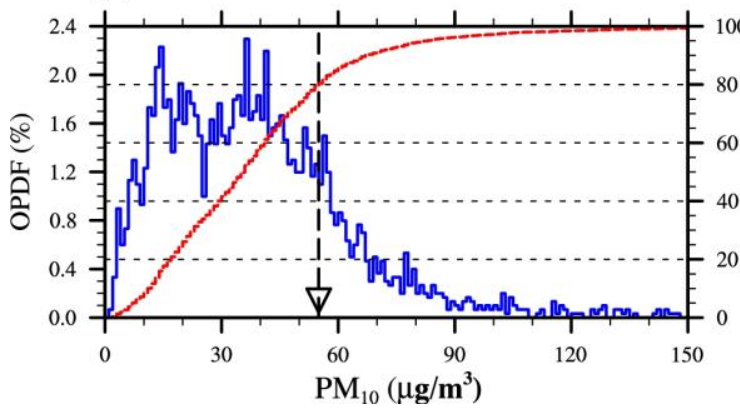

(d) Seoul

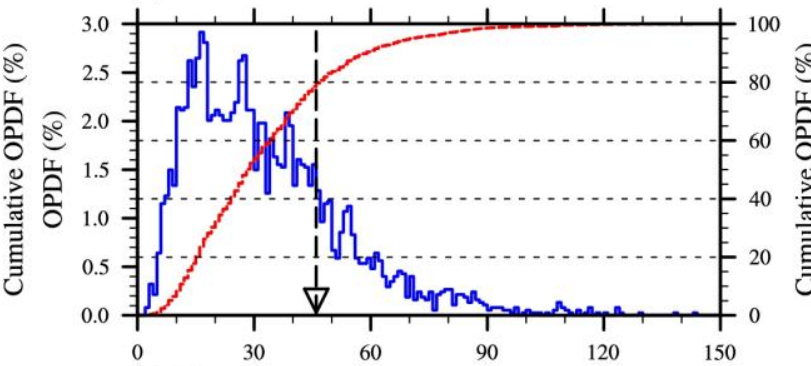

(e) Gunsan

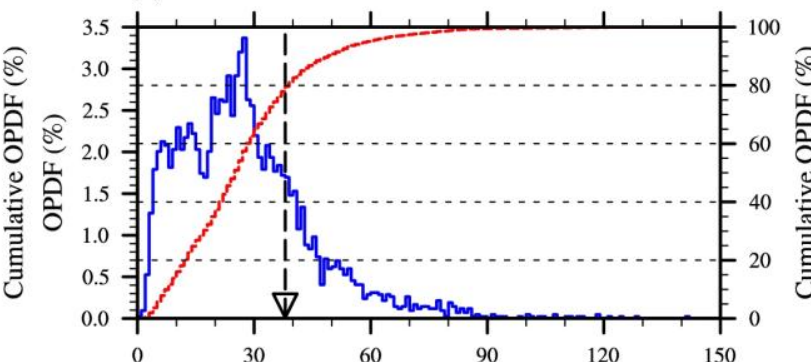

(f) Cheorwon

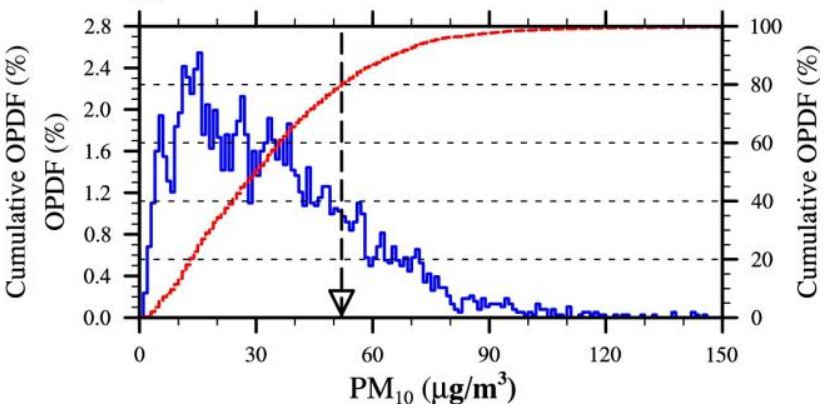

Figure 2. Occurrence probability density functions (blue solid line) and cumulative occurrence probability density functions (red dotted line) of the VIS $>20 \mathrm{~km}$ at (a) Baengnyeongdo, (b) Heuksando, (c) Munsan, (d) Seoul, (e) Gunsan and (f) Cheorwon. The arrows show the lowest PM10 concentration $\left(\mu \mathrm{g} \mathrm{m}^{-3}\right)$ that affects visibility reduction.

The Asian dust events are identified with the conditions; the ratio of the $\mathrm{PM}_{10}$ concentration to the $\mathrm{PM}_{1}$ concentration $\left(\mathrm{PM}_{10} / \mathrm{PM}_{1}\right)$ is equal or larger than 4 and the hourly mean $\mathrm{PM}_{10}$ concentration exceeds $90 \mu \mathrm{g} \mathrm{m}^{-3}$ at each site. This value is equivalent to the sum of the mean $\mathrm{PM}_{10}$ concentration and one half of the standard deviation observed in South Korea during the spring season (Park et al., 2012b). Figure 3 shows one of the examples to determine the duration of Asian dust event at each site. 
(a) Baengnyeongdo

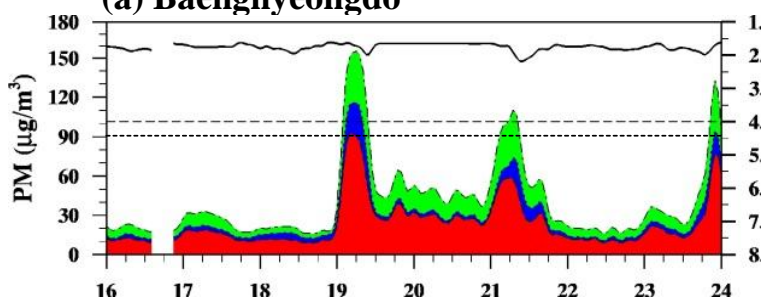

(b) Heuksando

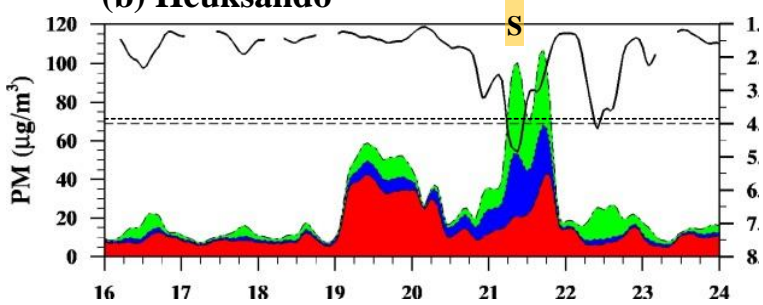

(c) Munsan

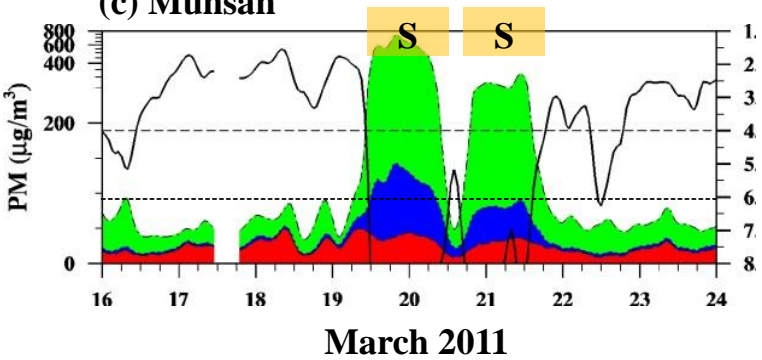

(d) Seoul

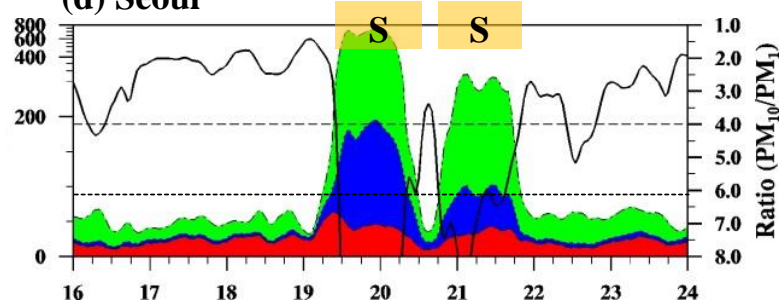

(e) Gunsan

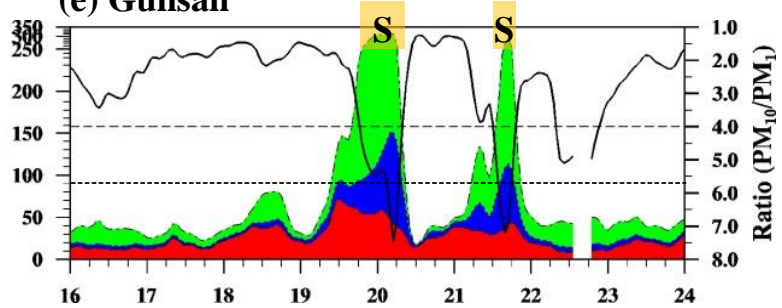

(f) Cheorwon

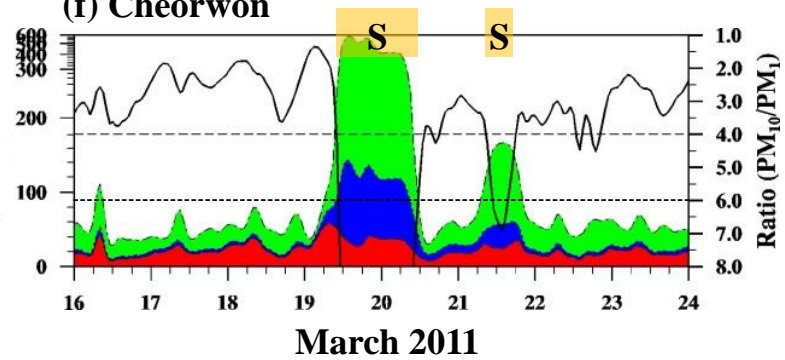

Figure 3. Time series of the observed size segregated aerosol mass concentration $\left(\mu \mathrm{g} \mathrm{m}^{-3}\right)$; $\mathrm{PM}_{1}$ (red), $\mathrm{PM}_{2.5}-\mathrm{PM}_{1}$ (blue) and $\mathrm{PM}_{10}-\mathrm{PM}_{2.5}$ (green), and the ratio of $\mathrm{PM}_{10}$ to $\mathrm{PM}_{1}$ (solid black line) at (a) Baengnyeongdo, (b) Heuksando, (c) Munsan, (d) Seoul, (e) Gunsan and (f) Cheorwon for the period of 16-23 March 2011. The hourly mean $\mathrm{PM}_{10}$ concentration of 90 $\mu \mathrm{g} \mathrm{m}^{-3}$ is indicated by a dotted line and the ratio $\left(\mathrm{PM}_{10} / \mathrm{PM}_{1}\right)$ of 4 is indicated by a dashed line. The Asian dust event period is indicated by " $\mathrm{S}$ "

The mist and haze events are identified from the time series of the hourly mean $\mathrm{PM}_{10}$ concentration that are excluded precipitation, fog and Asian dust events and the use of hourly mixing ratio calculated from the time series of the surface observation data. The mixing ratio trend curve is constructed with the use of consecutive 15-day mixing ratios. The mist event period is determined by the period when the hourly mean $\mathrm{PM}_{10}$ concentration obtained from the time series of the hourly mean $\mathrm{PM}_{10}$ concentration excluded the precipitation, fog and Asian dust events exceeds the lowest $\mathrm{PM}_{10}$ concentration value determined in Figure 2 and the mixing ratio is higher than the value determined by trend curve at that time. Whereas the haze event is determined with the same condition of mist for the $\mathrm{PM}_{10}$ concentration but the mixing ratio is lower than the value determined by the mixing ratio trend curve. The durations of the haze and the mist events determined by the above method are given in Figure 4 as an example. 
(a) Baengnyeongdo

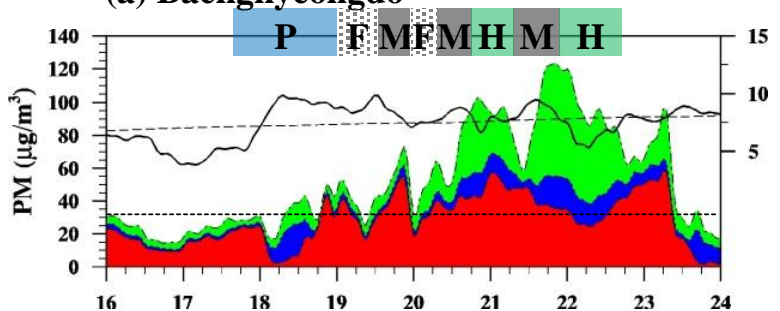

(b) Heuksando

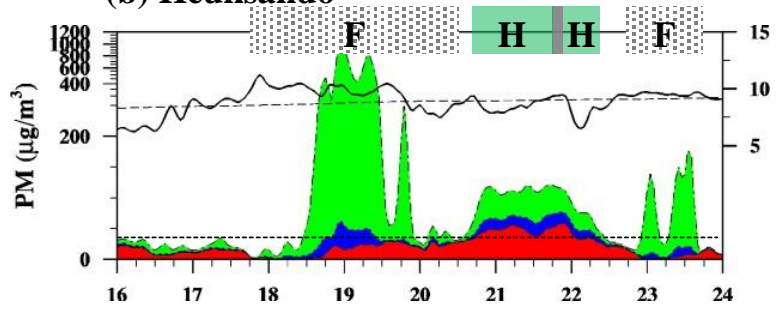

(c) Munsan

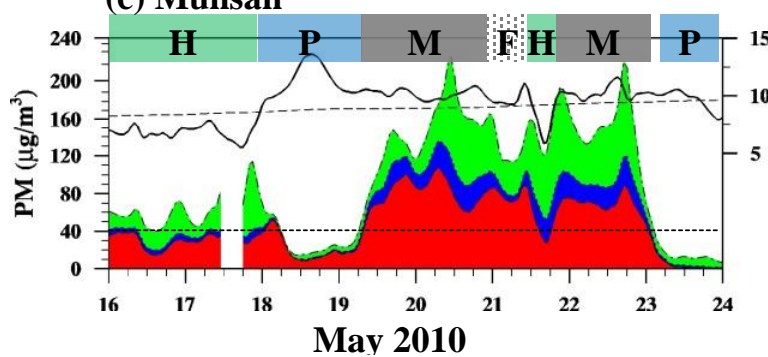

(d) Seoul

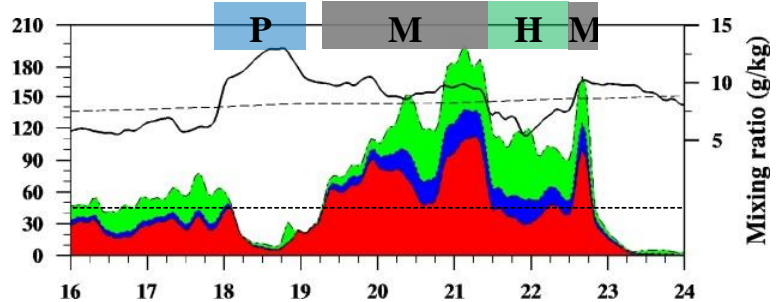

(e) Gunsan

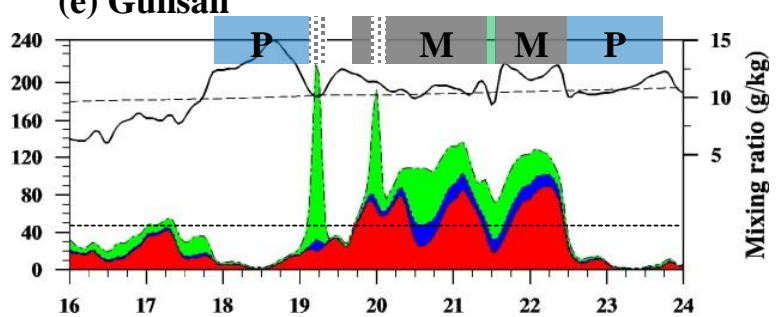

(f) Cheorwon

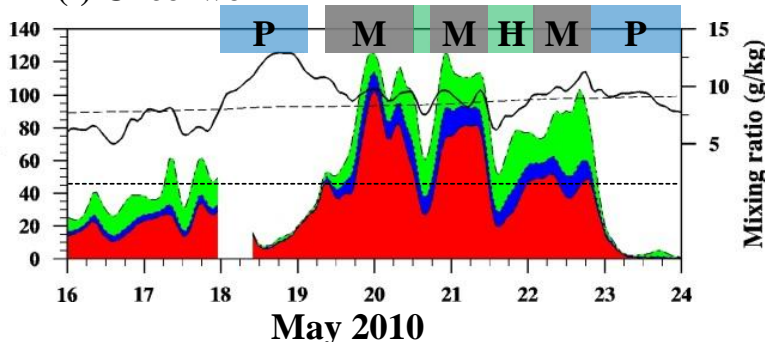

Figure 4. Time series of the hourly mean size segregated aerosol concentration $\left(\mu \mathrm{g} \mathrm{m}^{-3}\right)$; PM1 (red), $\mathrm{PM}_{2.5}-\mathrm{PM}_{1}$ (blue) and $\mathrm{PM}_{10}-\mathrm{PM}_{2.5}$ (green), and the mixing ratio (g/kg; solid black line) at (a) Baengnyeongdo, (b) Heuksando, (c) Munsan, (d) Seoul, (e) Gunsan and (f) Cheorwon for the period of 16-25 May 2010. The trend curve of the mixing ratio (dashed line), the lowest PM10 concentration (dotted line) to affect visibility and duration time periods of precipitation ( $\mathrm{P}$ ), fog ( F ), mist ( M ) and haze ( $\mathrm{H}$ ) are indicated.

\section{Occurrence Frequencies of Weather Events Associated with Aerosols in South Korea}

The methodology described in Section 3 is implemented to the time series of the observed hourly surface meteorological data and the hourly mean size segregated aerosol concentration data at 6 sites (Figure 1) for the three-year period (2009-2011) to find occurrence frequencies of weather events including precipitation, fog, mist, haze and Asian dust.

\subsection{Occurrence Frequencies of Weather Events}

Table 1. Percentage occurrence frequencies of weather events

\begin{tabular}{|c|c|c|c|c|c|c|}
\hline $\begin{array}{c}\text { Weather } \\
\text { event }\end{array}$ & $\begin{array}{c}\text { Baengnye- } \\
\text { ongdo }\end{array}$ & Heuksando & Munsan & Seoul & Gunsan & Cheorwon \\
\hline Precipitation & 12.9 & 12.2 & 9.6 & 12.9 & 11.8 & 12.8 \\
\hline Fog & 9.0 & 8.2 & 3.1 & 0.3 & 2.5 & 2.7 \\
\hline
\end{tabular}




\begin{tabular}{|c|c|c|c|c|c|c|}
\hline Asian dust & 1.1 & 1.0 & 2.4 & 2.1 & 1.1 & 1.9 \\
\hline Haze & 23.4 & 20.4 & 31.4 & 29.0 & 24.9 & 23.6 \\
\hline Mist & 18.8 & 12.6 & 20.0 & 20.5 & 16.2 & 15.5 \\
\hline Other & 34.7 & 45.6 & 33.5 & 35.1 & 43.6 & 43.6 \\
\hline Missing & 18.6 & 33.6 & 11.8 & 5.8 & 8.0 & 30.7 \\
\hline
\end{tabular}

"Other" represents other weather events not included in the listed weather events. "Missing" represents the percentage missing data of the whole analysis period of 3 years ( $26280 \mathrm{hr})$

Table 1 shows the percent occurrence frequencies of weather events that are associated with aerosols. "Other" in Table 1 includes clear weather and other than weather phenomena listed in Table 1.

The highest occurrence weather event is haze at all sites especially in the big city of Seoul and the inland site of Munsan (Figure 1), where more than 100 days in a year are affected by haze. Fog occurs more frequently at the island sties (Baengnyeongdo and Heuksando in Figure 1) than the inland sites while the occurrence frequency of precipitation and Asian dust events are almost the same at all sites, suggesting the importance of the synoptic scale motion for these events.

\subsection{Occurrence Frequencies of Meteorological Variables and Aerosol Concentrations in Association with Weather Events}

Occurrence frequencies of weather events in association with aerosols (Table 1) show a slightly different distribution patterns between the island sites (Baengnyeongdo and Heuksando) and the inland sites (Seoul, Munsan and Cheorwon). The inland site of Seoul and the island site of Baengnyeongdo (Figure 1) are chosen to make a comparison of the occurrence frequency distributions of visibility, relative humidity, $\mathrm{PM}_{10}$ concentration and the ratio of the $\mathrm{PM}_{10}$ to the $\mathrm{PM}_{1}$ concentration at these sites.

Figure 5 shows the occurrence frequency distribution of visibility, relative humidity, $\mathrm{PM}_{10}$ concentration and the ratio of the $\mathrm{PM}_{10}$ to the $\mathrm{PM}_{1}$ concentration in association with the weather events identified in section 3 at the inland site of Seoul. 
(a) Precipitation
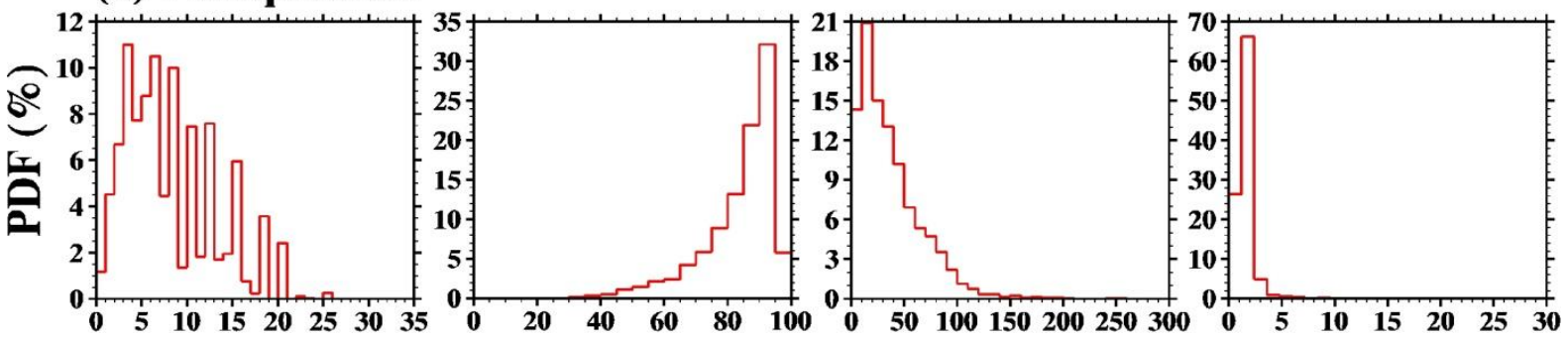

(b) Fog
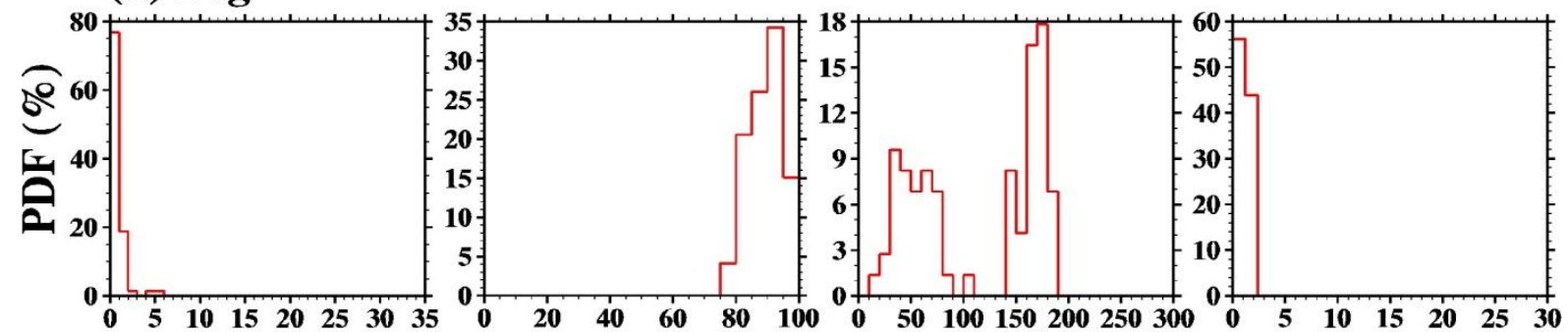

(c) Asian dust
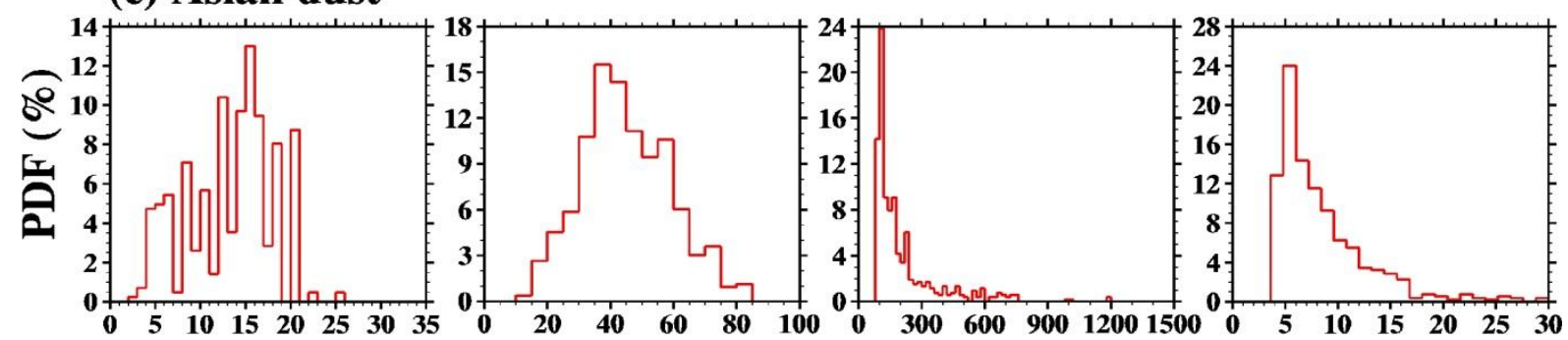

(d) Mist
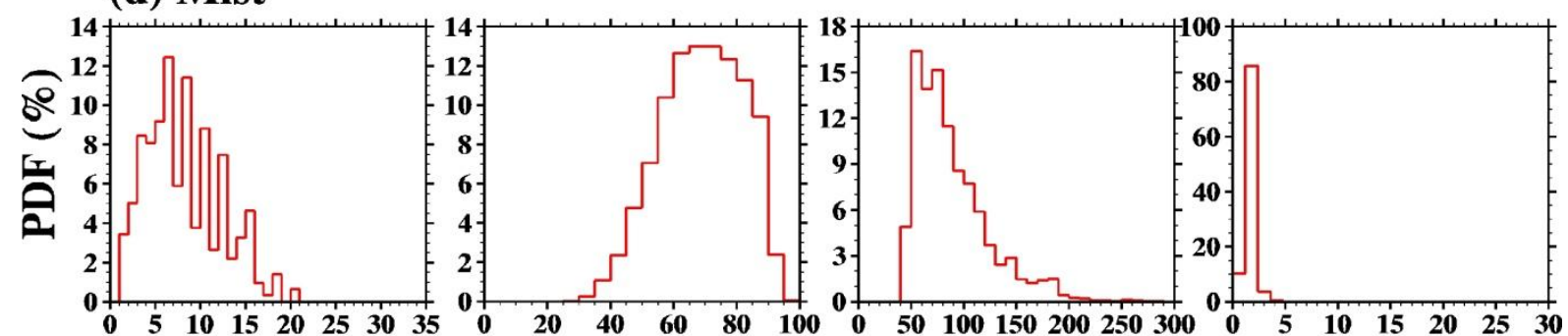

(e) Haze
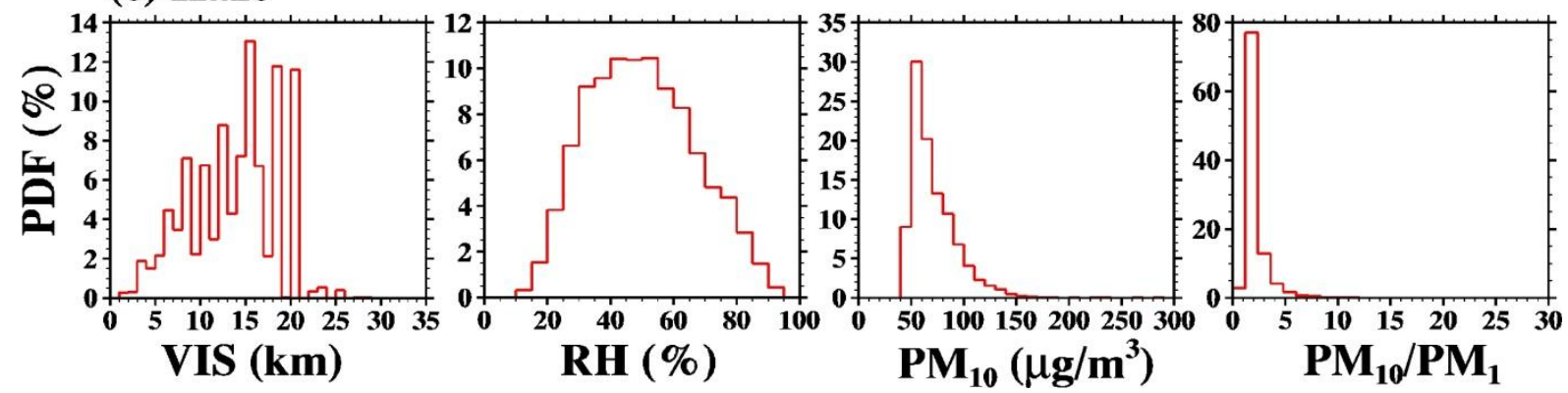

Figure 5. Variations of occurrence probability density function (PDF, \%) of visibility (km), relative humidity (\%), $\mathrm{PM}_{10}$ concentration $\left(\mu \mathrm{g} \mathrm{m}^{-3}\right)$ and the ratio of $\mathrm{PM}_{10}$ concentration to $\mathrm{PM}_{1}$ concentration in association with weather events of (a) precipitation, (b) fog, (c) Asian dust, (d) mist and (e) haze at the inland site of Seoul.

For the precipitation events at Seoul, the visibility ranges from $2 \mathrm{~km}$ to $21 \mathrm{~km}$ with the 
maximum occurrence frequency at $4 \mathrm{~km}$; the relative humidity exceeds $70 \%$ with the maximum occurrence frequency at $95 \%$; the $\mathrm{PM}_{10}$ concentration is less than $90 \mu \mathrm{g} \mathrm{m}^{-3}$ with the maximum occurrence frequency at $20 \mu \mathrm{g} \mathrm{m}^{-3}$ while the concentration ratio $\left(\mathrm{PM}_{10} / \mathrm{PM}_{1}\right)$ has its maximum occurrence frequency at 2 and extends up to 4 .

For the fog events at Seoul, the visibility is less than $1 \mathrm{~km}$ with the maximum occurrence frequency at $0.5 \mathrm{~km}$; the relative humidity exceeds $85 \%$ with the maximum occurrence frequency at $95 \%$; the $\mathrm{PM}_{10}$ concentration has two maximum occurrence frequencies at 40 $\mu \mathrm{g} \mathrm{m}^{-3}$ and $180 \mu \mathrm{g} \mathrm{m}^{-3}$; the concentration ratio $\left(\mathrm{PM}_{10} / \mathrm{PM}_{1}\right)$ varies up to 2 with the maximum occurrence frequency at 1 , suggesting the dominance of small particles.

For the Asian dust events at Seoul, the visibility varies up to $21 \mathrm{~km}$ from $9 \mathrm{~km}$ with the maximum occurrence frequency at $16 \mathrm{~km}$; the relative humidity ranges from $20 \%$ to $75 \%$ with the maximum occurrence frequency at $40 \%$; The maximum $\mathrm{PM}_{10}$ concentration reaches up to $1300 \mu \mathrm{g} \mathrm{m}^{-3}$ but the $\mathrm{PM}_{10}$ concentration has its maximum occurrence frequency at 120 $\mu \mathrm{g} \mathrm{m}^{-3}$; the concentration ratio $\left(\mathrm{PM}_{10} / \mathrm{PM}_{1}\right)$ has its maximum value of 28 with the maximum occurrence frequency at 6 , suggesting the predominance of larger particles.

For the mist events at Seoul, the visibility varies up to $16 \mathrm{~km}$ from $2 \mathrm{~km}$ with the maximum frequency at $7 \mathrm{~km}$; the relative humidity ranges from $45 \%$ to $95 \%$ with the maximum occurrence frequency at $70 \%$; the $\mathrm{PM}_{10}$ concentration ranges from $50 \mu \mathrm{g} \mathrm{m}^{-3}$ to $150 \mu \mathrm{g} \mathrm{m}^{-3}$ with the maximum occurrence frequency at $60 \mu \mathrm{g} \mathrm{m}^{-3}$; the concentration ratio $\left(\mathrm{PM}_{10} / \mathrm{PM}_{1}\right)$ extends up to 4 with the maximum occurrence frequency at 2.

For the haze events at Seoul, the visibility ranges from $7 \mathrm{~km}$ to $21 \mathrm{~km}$ with the maximum occurrence frequency at $16 \mathrm{~km}$; the relative humidity ranges from $25 \%$ to $85 \%$ with the maximum occurrence frequency at $50 \%$; the $\mathrm{PM}_{10}$ concentration ranges from $50 \mu \mathrm{g} \mathrm{m}^{-3}$ to $110 \mu \mathrm{g} \mathrm{m}^{-3}$ with the maximum occurrence frequency at $55 \mu \mathrm{g} \mathrm{m}^{-3}$; the concentration ratio $\left(\mathrm{PM}_{10} / \mathrm{PM}_{1}\right)$ varies up to 5 with the maximum occurrence frequency at 2.

Figure 6 shows those distributions in Figure 5 at the island site of Baengnyeongdo (Figure 1). For the precipitation events at the Baengnyeongdo site (Figure 6a), the visibility varies up to $21 \mathrm{~km}$ from $1 \mathrm{~km}$ with the predominant maximum occurrence frequency at $1 \mathrm{~km}$ that is much poorer visibility than that at the inland site (Figure 5a); the relative humidity exceeds $60 \%$ with the maximum occurrence frequency at $95 \%$ that is similar to that at the inland site; the $\mathrm{PM}_{10}$ concentration is less than $70 \mu \mathrm{g} \mathrm{m}^{-3}$ with the maximum occurrence frequency at $30 \mu \mathrm{g}$ $\mathrm{m}^{-3}$ that is slightly higher $\mathrm{PM}_{10}$ concentration than that at the inland site (Figure 5a); the concentration ratio $\left(\mathrm{PM}_{10} / \mathrm{PM}_{1}\right)$ extends up to 5 that is slightly larger value than that at the inland site (Figure 5a), suggesting the aerosol size at the island site being larger than that at the inland site.

For the fog events at the island site of Baengnyeongdo (Figure 6b), more than $87 \%$ of the occurrence frequency of the visibility is confined within the visibility less than $1 \mathrm{~km}$ with the relative humidity larger than $95 \%$ (Figure $6 \mathrm{~b}$ ); the $\mathrm{PM}_{10}$ concentration ranges from $20 \mu \mathrm{g} \mathrm{m}^{-3}$ to $60 \mu \mathrm{g} \mathrm{m}^{-3}$ with the maximum occurrence frequency at $30 \mu \mathrm{g} \mathrm{m}^{-3}$; the concentration ratio 
(a) Precipitation
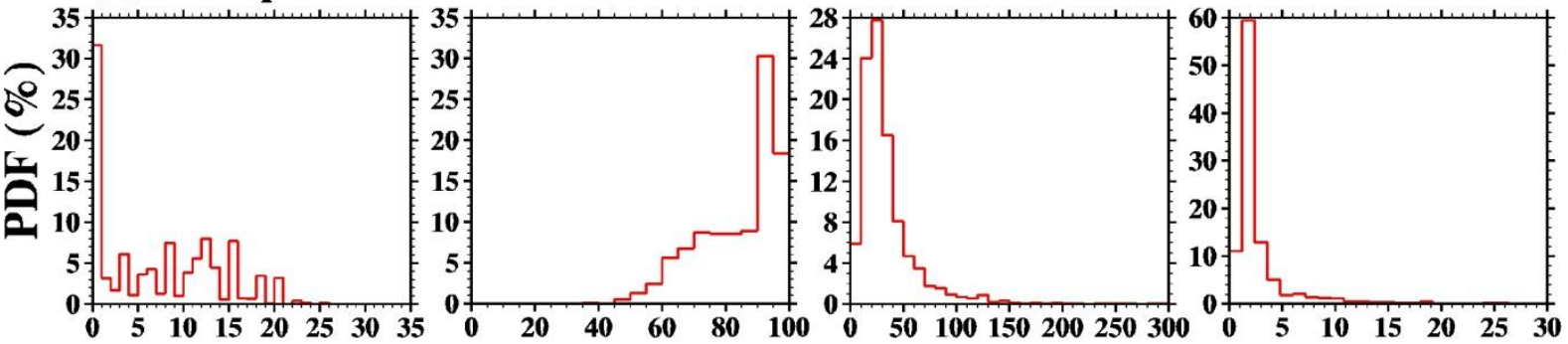

(b) Fog
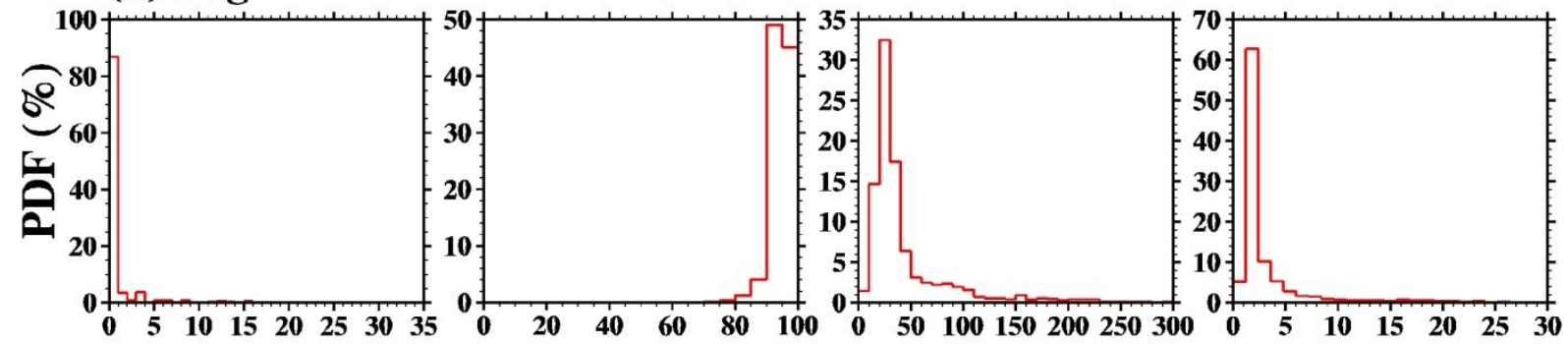

(c) Asian dust
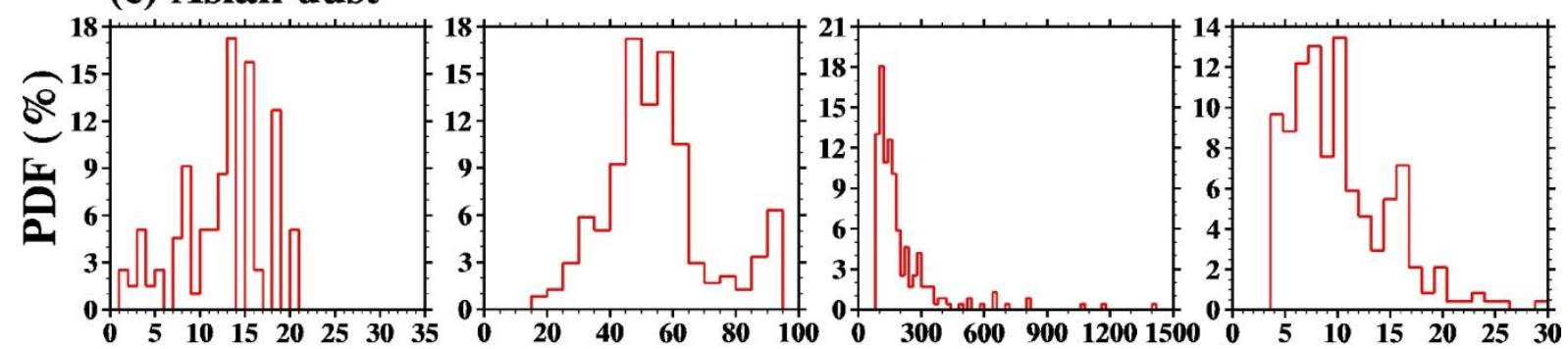

(d) Mist
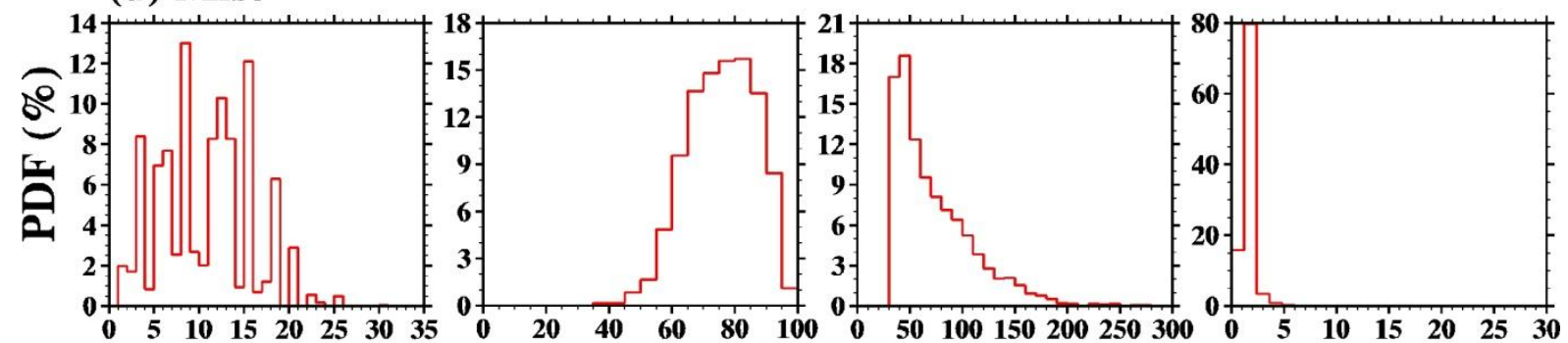

(e) Haze
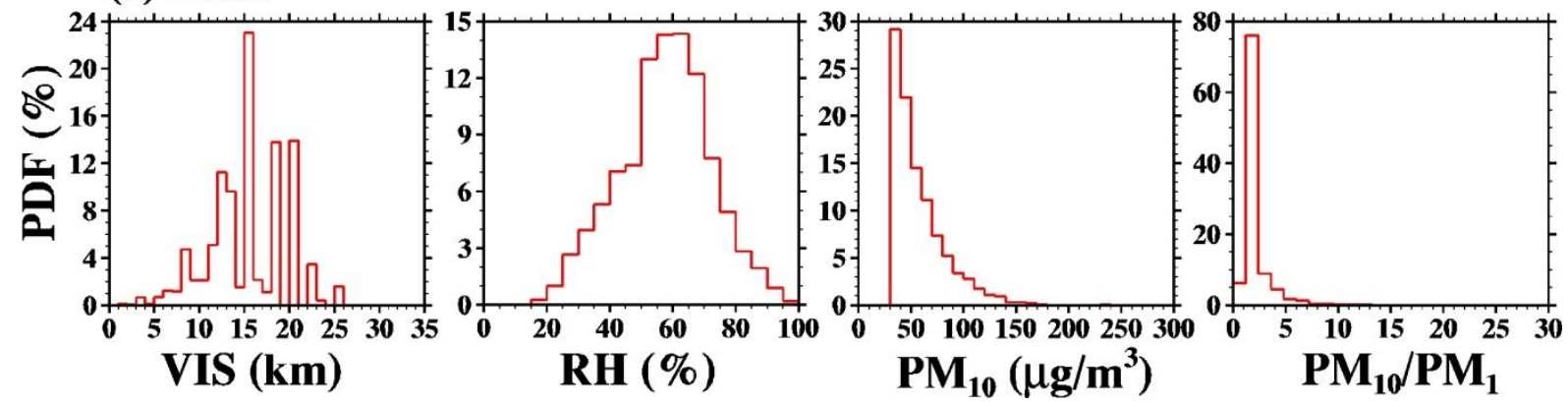

Figure 6. The same as in Figure 5 except for the island site of Baengnyeongdo.

$\left(\mathrm{PM}_{10} / \mathrm{PM}_{1}\right)$ extends up to 5 with its maximum occurrence frequency at 2 (Figure $6 \mathrm{~b}$ ), implying the fog forming aerosol size at the island site being larger than that at the inland site (Figure $5 \mathrm{~b}$ ) probably due to the sea salt. 
For the Asian dust events at the island site of Baengnyeongdo (Figure 6c), the visibility extends from $2 \mathrm{~km}$ to $21 \mathrm{~km}$ with the maximum occurrence frequency at $13 \mathrm{~km}$ that is a little poorer visibility than that at the inland site (Figure $5 \mathrm{c}$ ); the relative humidity ranges from $30 \%$ to $95 \%$ with the maximum occurrence frequency at $50 \%$ that is slightly higher than that at the inland site (Figure 5c); the maximum $\mathrm{PM}_{10}$ concentration has its maximum occurrence frequency at $150 \mu \mathrm{g} \mathrm{m}^{-3}$ (Figure 6c); the concentration ratio $\left(\mathrm{PM}_{10} / \mathrm{PM}_{1}\right)$ reaches up to 30 with its maximum occurrence frequency at 11 (Figure 6c). This clearly indicates that the size of aerosol for the Asian dust events at the island site (Figure 6c) is larger than that at the inland site (Figure 5c).

For the mist events at the island site of Baengnyeongdo (Figure 6d), the range of visibility is the same as that at the inland site (Figure $5 \mathrm{~d}$ ) but the maximum occurrence frequency occurs at $9 \mathrm{~km}$; the relative humidity extends from $60 \%$ to $95 \%$ with the maximum occurrence frequency at $85 \%$; the $\mathrm{PM}_{10}$ concentration ranges from $40 \mu \mathrm{g} \mathrm{m}^{-3}$ to $150 \mu \mathrm{g} \mathrm{m}^{-3}$ with the maximum occurrence frequency at $50 \mu \mathrm{g} \mathrm{m}^{-3}$; the concentration ratio $\left(\mathrm{PM}_{10} / \mathrm{PM}_{1}\right)$ is nearly the same as at the inland site (Figure 5d) with the maximum occurrence frequency at 2.

For the haze events at the Baengnyeongdo site (Figure 6e), the range of visibility ( $9 \mathrm{~km}$ to 23 $\mathrm{km}$ and its maximum occurrence frequency at $16 \mathrm{~km}$ ) and the relative humidity are almost the same as at the inland site, but the maximum occurrence frequency of the relative humidity is higher than that at the inland site of Seoul (Figure 5e); the $\mathrm{PM}_{10}$ concentration ranges from 45 $\mu \mathrm{g} \mathrm{m}^{-3}$ to $110 \mu \mathrm{g} \mathrm{m}^{-3}$ with the maximum occurrence frequency at $45 \mu \mathrm{g} \mathrm{m}^{-3}$; the concentration ratio $\left(\mathrm{PM}_{10} / \mathrm{PM}_{1}\right)$ has the similar occurrence frequency distribution to that at the inland site of Seoul (Figure 5e).

Above analyses indicate that the visibility reduction and the relative humidity in association with precipitation, fog and Asian dust events at the island site are higher than those at the inland site. The aerosol size in association with these weather events at the island site is larger than that at the inland site, probably due to the abundant sea-salt over the island site while the large amount of air pollutants over the inland site. However, there is of no significant difference between the island site and the inland site for mist and haze events, suggesting the importance of anthropogenic aerosols for these events.

Table 2 shows the characteristic features of weather events occurred at 6 sites in South Korea (Figure 1) during the period of 2009 to 2011.

Among all weather events, the highest mean visibility ranging from $13 \mathrm{~km}$ to $15 \mathrm{~km}$ occurs in association with haze events while the lowest mean visibility ranging from $0.8 \mathrm{~km}$ to $1.0 \mathrm{~km}$ is associated with fog events at all sites.

The Asian dust events have the lowest relative humidity while they have the largest concentration ratio $\left(\mathrm{PM}_{10} / \mathrm{PM}_{1}\right)$ among all weather events. Mist events cause poorer visibility due to higher relative humidity and aerosol concentration than haze events. The particle size causing mist is smaller but higher $\mathrm{PM}_{10}$ concentration than that of haze. Precipitation events cause the lowest $\mathrm{PM}_{10}$ concentration due to washout and scavenging effects. However, the aerosol particle sizes are not smaller than those of haze and mist as seen in the concentration 


\section{Macrothink}

Environmental Management and Sustainable Development

ISSN 2164-7682

2013, Vol. 2, No. 1

Table 2. Mean (standard deviation) values of visibility (VIS), relative humidity (RH), PM10 concentration $\left(\mu \mathrm{g} \mathrm{m}^{-3}\right)$ and the ratio of PM10 concentration to PM1 concentration in association with the visibility reducing weather events at 6 sites over South Korea for the 3-year period (2009-2011).

\begin{tabular}{|c|c|c|c|c|c|c|c|c|}
\hline & \multicolumn{4}{|c|}{ Baengnyeongdo } & \multicolumn{4}{|c|}{ Heuksando } \\
\hline & VIS (km) & $\mathrm{RH}(\%)$ & $\begin{array}{c}\mathrm{PM}_{10} \\
\left(\mu \mathrm{g} \mathrm{m}^{-3}\right)\end{array}$ & $\begin{array}{c}\text { Ratio } \\
\left(\mathrm{PM}_{10} / \mathrm{PM}_{1}\right)\end{array}$ & VIS (km) & $\mathrm{RH}(\%)$ & $\begin{array}{c}\mathrm{PM}_{10} \\
\left(\mu \mathrm{g} \mathrm{m}^{-3}\right)\end{array}$ & $\begin{array}{c}\text { Ratio } \\
\left(\mathrm{PM}_{10} / \mathrm{PM}_{1}\right)\end{array}$ \\
\hline PRCP & $7.0(6.3)$ & $84.1(12.3)$ & $57.6(233.3)$ & $3.1(4.7)$ & $9.2(6.0)$ & 83.5 (11.7) & $28.7(68.2)$ & $3.4(10.7)$ \\
\hline FOG & $0.9(2.2)$ & $94.3(2.9)$ & $144.3(484.7)$ & $4.5(9.0)$ & $0.8(1.5)$ & $94.6(2.7)$ & $88.1(176.9)$ & $10.7(22.0)$ \\
\hline DUST & $12.0(4.8)$ & $54.6(16.7)$ & $228.9(342.4)$ & $10.6(6.0)$ & $7.1(4.3)$ & $70.3(18.3)$ & $235.3(266.3)$ & $13.6(18.1)$ \\
\hline MIST & $10.5(5.0)$ & $75.9(10.8)$ & $71.5(38.8)$ & $1.5(0.5)$ & $10.2(4.8)$ & $76.9(10.0)$ & $57.8(28.0)$ & $1.7(1.7)$ \\
\hline \multirow[t]{3}{*}{ HAZE } & $15.1(4.3)$ & $57.7(14.5)$ & $55.3(24.7)$ & $2.0(1.4)$ & $13.5(4.8)$ & $70.1(15.1)$ & $49.6(17.8)$ & $2.1(1.7)$ \\
\hline & \multicolumn{4}{|c|}{ Munsan } & \multicolumn{4}{|c|}{ Seoul } \\
\hline & VIS $(\mathrm{km})$ & $\mathrm{RH}(\%)$ & $\begin{array}{c}\mathrm{PM}_{10} \\
\left(\mu \mathrm{g} \mathrm{m}^{-3}\right)\end{array}$ & $\begin{array}{c}\text { Ratio } \\
\left(\mathrm{PM}_{10} / \mathrm{PM}_{1}\right)\end{array}$ & VIS (km) & $\mathrm{RH}(\%)$ & $\begin{array}{c}\mathrm{PM}_{10} \\
\left(\mu \mathrm{g} \mathrm{m}^{-3}\right)\end{array}$ & $\begin{array}{c}\text { Ratio } \\
\left(\mathrm{PM}_{10} / \mathrm{PM}_{1}\right)\end{array}$ \\
\hline PRCP & $8.2(5.4)$ & $90.1(10.2)$ & $44.2(46.8)$ & $2.2(2.3)$ & $7.8(5.0)$ & $83.7(11.5)$ & $39.1(44.1)$ & $1.6(1.0)$ \\
\hline FOG & $0.9(1.6)$ & $95.5(2.9)$ & $80.7(46.6)$ & $1.5(0.2)$ & $1.0(0.7)$ & $89.4(5.2)$ & $114.1(59.1)$ & $1.2(0.1)$ \\
\hline DUST & $14.9(5.1)$ & $49.1(18.2)$ & $199.9(144.1)$ & $8.9(5.0)$ & $12.8(4.8)$ & $45.0(14.1)$ & 209.3 (164.5) & $8.5(4.4)$ \\
\hline MIST & $8.3(4.5)$ & $77.6(15.2)$ & $92.6(37.8)$ & $1.6(0.4)$ & $7.8(4.1)$ & $68.9(13.0)$ & $87.7(36.1)$ & $1.5(0.4)$ \\
\hline \multirow[t]{3}{*}{ HAZE } & $13.7(5.7)$ & $63.5(22.2)$ & $73.3(23.4)$ & $2.2(1.1)$ & $13.5(4.8)$ & $49.9(16.8)$ & $69.7(21.8)$ & $2.1(1.0)$ \\
\hline & \multicolumn{4}{|c|}{ Gunsan } & \multicolumn{4}{|c|}{ Cheorwon } \\
\hline & VIS (km) & $\mathrm{RH}(\%)$ & $\begin{array}{c}\mathrm{PM}_{10} \\
\left(\mu \mathrm{g} \mathrm{m}^{-3}\right)\end{array}$ & $\begin{array}{c}\text { Ratio } \\
\left(\mathrm{PM}_{10} / \mathrm{PM}_{1}\right)\end{array}$ & VIS (km) & $\mathrm{RH}(\%)$ & $\begin{array}{c}\mathrm{PM}_{10} \\
\left(\mu \mathrm{g} \mathrm{m}^{-3}\right)\end{array}$ & $\begin{array}{c}\text { Ratio } \\
\left(\mathrm{PM}_{10} / \mathrm{PM}_{1}\right)\end{array}$ \\
\hline PRCP & $9.7(5.3)$ & $89.4(10.2)$ & $31.9(33.5)$ & $1.6(1.1)$ & $8.8(5.0)$ & $87.1(9.7)$ & $39.4(90.2)$ & $2.0(1.9)$ \\
\hline FOG & $0.9(1.1)$ & $97.0(3.5)$ & $142.5(240.8)$ & $2.5(3.4)$ & $1.0(1.8)$ & $94.5(3.6)$ & $87.5(60.9)$ & $1.5(0.5)$ \\
\hline DUST & $10.9(5.1)$ & 68.2 15.9) & $221.1(158.9)$ & $7.5(3.0)$ & $12.6(5.2)$ & $49.8(17.4)$ & $198.1(131.2)$ & $8.4(3.9)$ \\
\hline MIST & $8.6(4.5)$ & $80.0(12.0)$ & $74.4(29.3)$ & $1.5(0.6)$ & $8.7(4.4)$ & $76.4(14.0)$ & $82.0(30.6)$ & $1.6(0.5)$ \\
\hline HAZE & $12.5(5.7)$ & $70.7(17.1)$ & $62.6(19.7)$ & $1.9(1.3)$ & $14.6(5.3)$ & $62.3(21.9)$ & $67.5(20.0)$ & $2.2(1.3)$ \\
\hline
\end{tabular}

ratio in Table 2. The large standard deviation of $\mathrm{PM}_{10}$ concentration at the island sites (Baengyeongdo, Heuksando) and the coastal site (Gunsan) in association with fog events may be caused by sea fogs that sometimes occur over the sea with high $\mathrm{PM}_{10}$ concentration.

\section{Conclusions}

Visibility reducing weather events affected by aerosols are examined with the use of hourly observed synoptic surface meteorological data and the hourly mean size segregated aerosol data in three steps $\left(\mathrm{PM}_{1}, \mathrm{PM}_{2.5}, \mathrm{PM}_{10}\right)$ measured at 6 sites in Korea for 3 years $(2009-2011)$. The methodology to identify weather events such as precipitation, fog, Asian dust, mist and haze has been developed using these data and implemented to the time series of these data to find the occurrence frequencies of these weather events. 


\section{Macrothink}

Environmental Management and Sustainable Development

ISSN 2164-7682

2013, Vol. 2, No. 1

It is found that the presently developed methodology is very useful to identify the haze event from the mist event and the Asian dust events that are very difficult for observers to distinguish them.

It is also found that haze events occur most frequently and followed by mist events in South Korea. These weather events are found to be related with relatively small aerosol particle sizes that might be originated from pollutant emissions.

It is also found that particles causing haze are drier, less $\mathrm{PM}_{10}$ mass concentration but larger sizes than those of mist.

The presently developed methodology for the identification of weather events may be useful to observers for their naked eye observations provided the size segregated aerosol concentration data.

\section{Acknowledgement}

This work was funded by the Korea Meteorological Administration Research and Development Program under Grant CATER 2012-2050. The observed dust concentration data are obtained from the National Institute of Meteorological Research in the Korea Meteorological Administration.

\section{References}

American Meteorological Society. (2000). Glossary of Meteorology (edited by Glickman TS). $850 \mathrm{pp}$.

Balásházy, I., Hofmann, W., \& Heistracher, T. (2003). Local particle deposition pattern may play a key role in the development of lung cancer. Journal of Applied Physiology, 94, 1719-1725.

Bates, D.V., Fish, B.R., Hatch, T.F., Mercer, T.T., \& Morrow, P.E. (1966). Deposition and retention models for internal dosimetry of the human respiratory tract. Health Physics, 12, 173-207.

Binkowski, F.S., \& Roselle, S.J. (2003). Models-3 Community Multiscale Air Quality (CMAQ) model aerosol component 1. Model description. Journal of Geophysical Research, 108(D6), 4183.

Chang L.-S., \& Park S.-U. (2004). Direct radiative forcing due to anthropogenic aerosols in East Asia during April 2001. Atmospheric Environment, 38, 4467-4482.

Che, H.Z., \& Zhang, X.Y. (2007). Horizontal Visibility Trends in China 1981-2005. Geophysical Research Letters, 34, http://dx.doi.org/10.1029/2007GL031450

Chun, Y., \& Lim, J.Y. (2004). The recent characteristics of Asian dust and haze event in Seoul, Korea. Meteorology and Atmospheric Physics, 87, 143-152.

Crutzen P. (2004). New directions: the growing urban heat and pollution island effect impact on chemistry and climate. Atmospheric Environment, 38, 3539-3540. 


\section{Macrothink}

Davis, M.E., Laden, F., Hart, J.E., Gashick, E., \& Smith, T.J. (2010). Economic activity and trends in ambient air pollution. Environmental Health Perspectives, 118, 614-619.

Dockery, D.W., Pope, C.A., Xu, X., Spengler, J.D., Ware, J.H., Fay, M.E., Ferris, B.G., \& Speizer, F.E. (1993a). An association between air pollution and mortality in six U.S. cities. New England Journal of Medicine, 329, 1753-1759.

Dockery, D.W., Pope, C.A. III, Xu, X., Spengler, J.D., Ware, J.H., Fay, M.E., Ferris, B.G., \& Speizer, F.E. (1993b). Mortality Risks of Air Pollution: A Prospective Cohort Study. New England Journal of Medicine, 329, 1753-1759.

Dockery, D.W., Schwartz, J., \& Spengler, J.D. (1992). Air Pollution and Daily Mortality: Associations with Particulates and Acid Aerosols. Environmental Research, 59, 362-373.

Gao, L., Jia, G., Zhang, R., Che, H., Fu, C., Wang, T., Zhang, M., Jiang, H., \& Yan, P. (2011). Visual Range Trends in the Yangtze River Delta Region of China, 1981-2005. Journal of the Air \& Waste Management Association, 61(8), 843-849.

Gao, Q.X., Li, L.J., Zhang, Y.G., \& Hu, M. (2000). Studies on the springtime dust storm of China. China Environmental Science, 20(6), 495-500.

Gautam, R., Hsu, N.C., Kafatos, M., \& Tsay, S.C. (2007). Influences of winter haze on fog/low cloud over the Indo-Gangetic plains. Journal of Geophysical Research, 112, D05207. http://dx.doi.org/10.1029/2005JD007036.

Guo, J., Zhang, X., Cao, C., Che, H., Liu, H., Gupta, P., Zhang, H., Xu, M., \& Li, X. (2013). Monitoring haze episodes over the Yellow Sea by combining multisensory measurements. International Journal of Remote Sensing, 31, 17-18, 4743-4755.

Husar, R.B., Tratt, D.M., Schichtel, B.A., Falke, S.R., Li, F., Jaffe, D., ... Malm, W.C. (2001). The Asian dust events of April 1998. Journal of Geophysical Research, 106, 18317-18330.

In, H.-J., \& Park, S.-U. (2002). The soil particle size dependent emission parameterization for an Asian dust (Yellow Sand) observed in Korea on April 2002. Atmospheric Environment, 37, 4625-2636.

Intergovernmental Panel on Climate Change. (1996). Climate Change 1995: The science of Climate change. Cambridge University Press. 573 pp.

Jacobson, M.Z. (2001). Strong radiative heating due to the mixing state of black carbon in atmospheric aerosols, Nature, 409, 695-697.

Jung, J., Lee, H., Kim, Y.J., Liu, X., Zhang, Y., Gu, J., \& Fan, S. (2009). Aerosol chemistry and the effect of aerosol water content on visibility impairment and radiative forcing in Guangzhou during the 2006 Pearl River Delta campaign. Journal of Environmental Management, 90, 3231-3244.

Kaufman, Y.J., Tanré, D., \& Boucher, O. (2002). A satellite view of aerosols in the climate system, Nature, 419, 215-223. 
Kim, K.W., Kim, Y.J., \& Bang, S.Y. (2008). Summer time haze characteristics of the urban atmosphere of Gwangju and the rural atmosphere of Anmyon, Korea. Environmental Monitoring and Assessment, 141, 189-199.

Lee, Y.L., \& Sequeira, R. (2001). Visibility degradation across Hong Kong: its components and their relative contributions. Atmospheric Environment, 34, 5861-5872.

Lee, K.H., Kim, Y.J., \& Kim, M.J. (2006). Characteristics of aerosol observed during two severe haze events over Korea in June and October 2004, Atmospheric Environment, 40, 5146-5155.

Menon, S., Hansen, J., Nazarenko, L., \& Luo, Y. (2002). Climate effects of black carbon aerosols in China and India. Science, 297, 2250-2253.

Park, S.-U., Choe, A., \& Park, M.-S. (2012b). A simulation of Asian dust events in March 2010 by using the ADAM2 model. Theoretical and Applied Climatology, 107, 491-503.

Park, S.-U., Cho. J.H., \& Park. M.-S. (2012). A simulation of Aerosols in Asia with the use of ADAM2 and CMAQ. Advances in Fluid Mechanics and Heat \& Mass Transfer. 258.

Park, S.-U., \& In, H.-J. (2003). Parameterization of dust emission for the simulation of the yellow sand (Asian dust) observed in March 2002 in Korea. Journal of Geophysical Research, 108(D19), 4618.

Park. S.-U., \& Lee. E.-H. (2004). Parameterization of Asian dust (Hwangsa) particle-size distributions for use in dust emission model. Atmospheric Environment, 38, 2155-2162.

Penner, J.E.P., Dong, X., \& Chen, Y. (2004). Observational evidence in radiative forcing due to the indirect aerosol effect. Nature, 427, 231-234.

Pope, C.A., Schwartz, J., \& Ransom, M.R. (1992). Daily mortality and PM $_{10}$ pollution in Utah valley. Archives of Environmental Health, 47(3), 211-217.

United Kingdom Meteorological Office. (1994). Handbook of Aviation Meteorology. 412pp.

Wang, K., Dickinson, R.E., \& Liang, S. (2009). Clear sky visibility has decreased over land globally from 1973 to 2007. Science, 323, 1468-1470.

Watson, J. G. (2002). Visibility: Science and regulation. Journal of the Air \& Waste Management Association, 52, 628-713.

World Meteorological Organization. (1980). Compendium of lecture notes for training Class IV meteorological personnel Volume II - Meteorology, WMO Technical Publication (edited by Retallack BJ). WMO-No. 266.

World Meteorological Organization. (2008). Guide to meteorological instruments and methods of observation (7th ed.). WMO-No. 8

World Meteorological Organization. (2008). Aerodrome Reports and Forecasts: A User's Handbook to the Codes. 81pp 


\section{Macrothink}

Environmental Management and Sustainable Development

ISSN 2164-7682 2013, Vol. 2, No. 1

Yadav, A.K., Kumar, K., Kasim, A., Sing, M.P., Parida, S.K., \& Sharan, M. (2003). Visibility and incidence of respiratory diseases during the 1998 haze episode in Brunei Darussala. Journal of the Air \& Waste Management Association, 53, 946-956.

Yu, X, Zhu, B., Yin, Y., Yang, J., Li, Y., \& Bu, X. (2011). A comparative analysis of aerosol properties in dust and haze-fog days in a Chinese urban region. Atmospheric Research, 99, 241-247.

\section{Copyright Disclaimer}

Copyright reserved by the author(s).

This article is an open-access article distributed under the terms and conditions of the Creative Commons Attribution license (http://creativecommons.org/licenses/by/3.0/).o 